\title{
Influence of women's empowerment indices on the utilization of skilled maternity care: evidence from rural Nigeria
}

\author{
Lorretta Favour C. Ntoimo $^{1,2 *}$ (D), Friday E. Okonofua ${ }^{2,3,4}$, Josephine Aikpitanyi ${ }^{3}$, Sanni Yaya ${ }^{5,6}$, \\ Ermel Johnson ${ }^{7}$, Issiaka Sombie ${ }^{7}$, Olabisi Aina ${ }^{8}$ and Wilson Imongan ${ }^{1}$ \\ ${ }^{1}$ Federal University Oye-Ekiti, Nigeria, ${ }^{2}$ Women's Health and Action Research Centre (WHARC), Benin City, Nigeria, \\ ${ }^{3}$ Centre of Excellence in Reproductive Health Innovation, University of Benin, Benin City, Nigeria, ${ }^{4}$ Department of \\ Obstetrics and Gynaecology, University of Benin and University of Benin Teaching Hospital, Nigeria, ${ }^{5}$ University of \\ Ottawa, Canada, ${ }^{6}$ The George Institute for Global Health, University of Oxford, UK, ${ }^{7}$ West African Health Organization, \\ Burkina Faso and ${ }^{8}$ Department of Sociology/Anthropology, Obafemi Awolowo University, Ile-Ife, Nigeria \\ ${ }^{\star}$ Corresponding author. Email: lorretta.ntoimo@fuoye.edu.ng
}

(Received 19 June 2020; revised 12 October 2020; accepted 12 October 2020; first published online 02 December 2020)

\begin{abstract}
There is increasing evidence that women with the ability to exercise control over their sexual and reproductive lives have greater access to prompt prevention and treatment of maternal health disorders, resulting in a concomitant reduction in maternal morbidity and mortality. This study assessed the association between indices of women's empowerment and utilization of skilled antenatal, intrapartum and postnatal maternity care in two rural Local Government Areas in Edo State, Nigeria. Data were taken from a household survey conducted in July and August 2017, and the study sample comprised 1245 ever-married women currently in a union who had given birth in the 5 years preceding the survey. A Gender Roles Framework guided the selection of independent women's empowerment variables. Using hierarchical logistic regression, the likelihood of receiving all three levels of skilled maternal health care service (antenatal, intrapartum and postnatal) by women's empowerment variables, grouped into resource, decision-making and influencer domains following the model of Anderson and Neuman, was assessed. Of the resource domain variables, respondent's education and respondent's participation in payment for their own health care positively predicted their use of all three levels of skilled maternal care, whereas their ownership of land negatively predicted this. Two decision-making domain variables were significantly associated with respondent's use of all three levels of service: those who made decisions alone about major household purchases were twice as likely to use all three levels of services than when decisions were made by their partners or others, while respondent making decisions alone about what food to cook each day was a negative predictor. Of the influencer variables, religion and a large spousal education gap were strong positive factors, whereas living in a consensual union rather than being legally married was a negative factor. Although health system factors are important, interventions geared towards changing gender norms that constrain women's empowerment are critical to achieving maternal health-related development goals in Nigeria. A composite strategy that targets all women's empowerment indices is recommended, as Nigeria strives towards achieving SDG-3.
\end{abstract}

Keywords: Skilled maternity care; Women's empowerment; Maternal health services

\section{Introduction}

Maternal health refers to the promotion of the well-being of women in pregnancy, during childbirth and after delivery. Improving access to quality maternal health care is one of the targets that have been 
identified for achieving Sustainable Development Goal 3 (SDG-3; WHO, 2016). However, despite efforts devoted to strengthening maternal health care services in many developing countries, maternal mortality remains a major public health challenge. Nigeria's maternal mortality ratio is estimated at 814 deaths per 100,000 live births with 58,000 maternal deaths annually (WHO, 2015a). Although the causes and determinants of these deaths vary from place to place, a major contribution to this problem is women's limited access to quality maternal health care, especially in rural communities. In Nigeria, primary health care has been identified as the gateway to the health care system, guaranteeing the attainment of universal health coverage in the country. Not only are Primary Health Centres (PHCs) available in most rural communities - they also provide personalized health care services that address the cultural and social lives of rural women (WHO, 1978; Federal Government of Nigeria, 2013; Azuh et al., 2017; Edo State Government, 2018). However, several lines of research have shown that many women in many communities, rather than using PHCs as the primary entry point into the formal health care system, prefer the use of unorthodox methods of maternal health care (Galadanci et al., 2007; Ebuehi \& Akintujoye, 2012; Sialubanje et al., 2015; Eshiet et al., 2016; Ntoimo et al., 2019). A previous study in rural Edo, Nigeria, showed that of 1408 women, only $46 \%$ had used or were currently using the available PHCs in their vicinity for maternity care (Okonofua et al., 2018).

Among several reasons identified as associated with the use or non-use of PHCs for maternal care by women in rural Nigeria, the consent and preferences of husbands are among the most prominent (Okonofua et al., 2018). Studies indicate that the limited decision-making power of women influences their ability to seek health care from skilled attendants (Bloom et al., 2001; Banda et al., 2016; Chol et al., 2019; Ntoimo \& Odusina, 2019). This indicates that a spouse's decision takes precedence over those of a woman, even in life-threatening health situations such as those posed by obstetric emergencies. In effect, women are either subjected to collective decision-making with their partners or they rely completely on the decisions of their partners on issues related to their reproductive lives (Titus et al., 2017). The dominating influence of men on women's reproductive health-seeking behaviour has been documented in previous studies in Nigeria and other African countries (DeRose \& Ezeh, 2005; Izugbara \& Ezeh, 2010).

This study aimed to examine the relationship between women's empowerment indices and the utilization of skilled maternal health care in rural Nigeria.

\section{Women's empowerment and reproductive health}

There is increasing evidence that the ability of women to exercise control over their sexual and reproductive lives would increase access to, and promote the prevention and treatment of maternal health disorders, resulting in a concomitant reduction in maternal morbidity and mortality (Woldemicael, 2007; Fawole \& Adeoye, 2015; Chol et al., 2019). This would be dependent on addressing women's autonomy and empowerment - key components of gender equality. To be empowered as a woman spans beyond mere permission; it expands to the freedom of choice the woman takes to shape her life (Gram et al., 2019). The Beijing Platform for Action defines women's empowerment as 'women's full participation in all spheres of society, including participation in the decision-making process based on equality' (UN Women, 2014). Other authors conceptualize empowerment as the power of a woman to have decision-making authority, including power to solve problems that can be creative and enabling (Dixon-Mueller, 1998; Mosedale, 2005). The Copenhagen Declaration (World Summit) on Social Development called for the recognition that empowering people, particularly women, to strengthen their capacities is the main objective of development and that empowerment requires the full participation of people in the formulation, implementation and evaluation of decisions determining the functioning and well-being of societies (United Nations, 1995). This suggests that the principle of shared power and responsibility between women and men should be mainstreamed at home, in the workplace and in the wider national and international community, as part of a logical approach to promote gender equality (UN Women, 2014). 
Maternal health-seeking behaviour is a complex phenomenon that not only depends on the availability of health care services but also demographic, cultural, social and personal factors that enable the demand of services (Ahmed et al., 2010). Several studies have reported the positive association between women empowerment and improved indicators of reproductive health, such as the ability to negotiate safe sex (Sano et al., 2018), contraceptive use (Ahmed et al., 2010; Bamiwuye et al., 2013) and the use of maternal health services (Dairo \& Owoyokun, 2010; Fawole \& Adeoye, 2015; Chol et al., 2019; Ntoimo \& Odusina, 2019; Sripad et al., 2019). For instance, using data obtained from the Demographic and Health Survey in 33 countries (21 in Africa), Ahmed et al. (2010) examined the magnitude of the association between women's economic, educational and empowerment status and three reproductive health outcomes related to MDGs 1-3: modern contraceptive use, attendance at four or more antenatal care (ANC) visits and skilled attendance at birth. They measured empowerment with a composite variable generated from the sum of five autonomy questions on participation in five household decisions. Women with the highest decision-making power were more likely than their counterparts with no decision-making power to use modern contraceptives, attend four or more ANC visits and receive skilled care during childbirth. Studies have equally reported that women who have substantive autonomy are more likely to discuss their reproductive health issues with their male partners (Oladeji, 2008; Abada \& Tenkorang 2012). Other studies report that when women can choose the sex of their health practitioner, the outcome of their health is more favourable (Camerini et al., 2012). However, empowerment does not predict the utilization of maternal health care services in all contexts. In a multi-country study conducted by Chol et al. (2019), women with more autonomy in Mali, Chad and Senegal were less likely to attend four or more ANC visits and have skilled delivery care, possibly because existing cultural norms and practice prevent their use of services, even when they have autonomy.

Most of these studies measured empowerment only in terms of decision-making autonomy as indicated by participation in household decision-making, attitudes to wife-beating, income earned by wife relative to her partner and education (Upadhyay et al., 2014). Also, there has been a preponderance of focus in many studies on a single level of care such as antenatal, intrapartum or postnatal care. Some studies examined two levels of care; however, studies that examined the likelihood of obtaining all three levels of care during pregnancy were less common. Accessing one level of care is not adequate to prevent pregnancy-related mortality and morbidity. The World Health Organization recommends that a pregnant woman should receive skilled antenatal, intrapartum and postnatal care (WHO, 2014, 2015b, 2015c). Despite this, and the efforts of Nigeria's Federal Ministry of Health to promote skilled care during pregnancy through its Safe Motherhood Programme, a large number of women in the country do not access all three levels of care during pregnancy. Although the percentage of women who access at least one ANC visit has continued to increase, the percentage who return for skilled intrapartum and postnatal care remains unacceptably low. For instance, the percentage of women age 15-49 years who receive skilled antenatal care increased from $58 \%$ in 2008 to $67 \%$ in 2018 , whereas delivery in a health facility over the same period increased by 4 percentage points - from $35 \%$ to $39 \%$. The percentage who received no postnatal check-ups remained at $56 \%$ in the 10 -year period (NPC \& ICF, 2019). The variation by place of residence is still wide. In 2018, $84 \%$ received skilled antenatal care in urban areas compared with $56 \%$ in rural areas; delivery in a health facility was $61 \%$ in urban areas and $26 \%$ in rural areas; and the percentage who did not receive a postnatal check in urban areas was $36 \%$, and $69 \%$ in rural areas (NPC \&ICF, 2019).

Very few attempts have been made to assess maternal health services utilization among rural women in Nigeria as a function of women's empowerment in relation to human capital, participation in household decision-making and economic resources such as employment and ownership of land and house. The current study sought to relate the above women empowerment domains to maternal health-seeking behaviour, as indicated by utilization of skilled antenatal, intrapartum and postnatal care in two rural Local Government Areas (LGAs) in Edo State, Nigeria. The outcome of this study will help design interventions to address women's empowerment and reproductive health in the country. 


\section{Methods}

\section{Study design, setting and population}

This study was part of the baseline household survey of a larger intervention research designed to improve women's access to skilled pregnancy care conducted from $29^{\text {th }}$ July to $16^{\text {th }}$ August 2017 in two rural LGAs (Esan South East and Etsako East) in Edo State, southern Nigeria. The two LGAs were purposively selected from the eighteen LGAs in Edo State. The two LGAs are comprised of rural communities with farming as their major source of livelihood. The study population was an unweighted sample of 1408 ever-married women aged 15-45 years who were randomly selected from 3462 households in 20 communities in the two LGAs: 707 from Estako East and 701 from Esan South East. Details of the sampling technique have been described elsewhere (Okonofua et al., 2018). The sample for this paper was limited to 1245 ever-married women who were currently married or in a consensual union, and who had at least one live birth in the 5 years preceding the survey, and excluded women who were pregnant for the first time (primigravid women).

\section{Data collection}

The data were collected through a household survey using a pre-tested structured questionnaire. The questionnaire was administered by trained interviewers employing a computer-assisted personal interviewing (CAPI) technique. The interview questions were asked either in English or Pidgin English depending on the respondent's choice, and the interviews lasted for an average of 40 minutes. The data encompassed information on socio-demographic characteristics, socioeconomic status measures, participation in household decision-making, ownership of land or house, and the places where antenatal, intrapartum and postnatal care were received, among others.

\section{Variables}

Dependent variable

The outcome (dependent) variable was 'skilled maternal health service utilization', measured by respondent's use of a health facility for antenatal, intrapartum and postnatal care. The respondents were asked where they received antenatal care, delivered and received a postnatal check for their most recent birth within the 5 years before the survey. Their current pregnancy was excluded from the analysis because the three levels of care had not all been completed. The response for each level of care was collapsed into two categories: use of any health facility (public or private) was coded ' 1 ', whereas use of a traditional birth attendant or home care was coded ' 0 '. The expected scores ranged from 0 to 3, where 0 was 'used no health facility for all three levels of care', 1 was 'used a facility for only one level of care', 2 was 'used a facility for 2 levels of care' and 3 was 'used facility for all three levels of care'. The scores were categorized into two for analysis: 'received fewer than three levels of skilled care' coded 0, and 'received all three levels of skilled care' coded 1.

\section{Predisposing, enabling and need variables}

The selection of independent variables was informed by past studies and the Anderson and Newman model of the utilization of health services (Andersen \& Newman, 2005). This model proposes that the use of health care services is a function of three sets of individual characteristics: predisposing, enabling and need factors. Predisposing factors reflect the fact that women with different characteristics have a different propensity to use health care services, and in this study included age, education, spousal age gap, spousal education gap, age at marriage, marital status, type of union, religion, place of residence (LGA) and participation in household decisions about major purchases, daily purchases, visits to respondent's friends and relatives and food to be cooked daily. Enabling factors reflect the fact that some women, even if predisposed to use health 
services, must have some means to obtain them, and in this study included employment status, ownership of land or house, participation in payment for the respondent's health and participation in decision about how to spend income the respondent earns. According to Andersen and Newman's framework, the need factor is the most immediate determinant of health service utilization, reflecting perceived health status. Here, the following need variable was included: participation in decisions about the respondent's own health.

\section{Women's empowerment variables}

The Gender Roles Framework developed by the Harvard Institute for International Development (March et al., 1999) provided a guide to selecting women's empowerment variables for the study. The framework is considered a useful tool for understanding women's and men's roles in society and takes account of external forces that affect development planning. It is based on an efficiency approach - an economic case for allocating resources to women as well as men. The framework organizes women's empowerment variables into three indicative domains: 'decision-making', 'resource' and 'influencer factors'. In the current study, women's empowerment variables were grouped into these three domains as described below.

'Decision-making' variables included respondent's participation in six household decisions: respondent's income, health, major household purchases, daily household purchases, visits to family and relatives and food to be cooked each day. The survey response options to questions on participation in household decisions were respondent alone, partner alone, respondent \& partner, and other person. A respondent who decides alone, or with her partner, is considered empowered, whereas one whose partner alone or others decide is considered not empowered. Thus, for the purpose of this analysis, these responses were re-categorized into three categories: 'partner alone or others', 'respondent alone' and 'respondent \& partner'. Many previous studies aggregated responses to decision-making variables to generate a single index of autonomy or empowerment (Bamiwuye et al., 2013; Fawole \& Adeoye, 2015; Ntoimo \& Odusina, 2019), while others aggregated them with other measures such as education or employment status (Upadhyay \& Hindin, 2005; Woldemicael, 2009). In the current study, each decision-making measure was included as a single variable. This provided more specific insight into women empowerment as regards the different aspects of decision-making power in the household (Upadhyay et al., 2014).

'Resource domain' variables comprised human capital and economic resources. The variable included to represent human capital variable was highest level of education achieved (no education, primary, and secondary/higher) as a woman is considered empowered if she attains at least a secondary education (UNDP, 2018). Economic resources variables included employment status (working, not working), ownership of land or house (none, partner alone/other, respondent alone, and respondent \& partner) and who pays for the respondent's health care (partner alone/other person, respondent alone, and respondent \& partner). It is cultural for women to own land or a house in the study location through inheritance or self-effort.

'Influencer factor' domain variables comprised those considered emblematic of gender norms and beliefs. In this study they included religion categorized into Catholic, Other Christian and Islam. Previous studies associated religion with gender inequality and women autonomy (Jejeebhoy \& Sathar, 2001; Seguino, 2011), and maternal and child health outcomes (Antai, 2011). Marital status was categorized into 'married' and 'living together with a partner', the latter being considered informal and indicative of personal perception about union formation. Another influencing factor was age at first marriage, categorized as $<18$ years and $\geq 18$ years. Marriage before 19 is considered a norm that inhibits women's empowerment, and a high proportion of women marrying before 18 is suggestive of a patriarchal culture that promotes male control of women's sexuality (Walby, 1989; Boye et al., 1991; Akpan, 2003). Number of co-wives (monogamy/polygyny) was included as this is often embedded in patriarchal culture and religion (Izugbara, 2004; Seguino, 2011). Other proxies of gender norms included in this domain were the spousal age gap and the gap 
between the respondent and her partner in educational attainment. Heterosexual familial ideologies and patriarchy still support early marriage and a traditional mate selection pattern, where men prefer women who are younger, attractive, less educated and earn less (Walby, 1989; Hakim, 2010)

\section{Data analysis}

Data analysis was conducted with Stata 13.0 for Windows. This included a description of the background characteristics of the respondents in frequencies, percentages and summary statistics where applicable. The degree of association between the dependent and explanatory variables was assessed using the chi-squared test and multivariable logistic regression. To observe the crude and net effect of the different domains of women empowerment on maternal health services utilization, each empowerment domain was modelled separately and a full model was estimated using all the variables. In all, four logit models were estimated: Model 1 contained resource variables, Model 2 decision-making variables, Model 3 influencer variables and Model 4 was the full model. Statistical significance was set at $p<0.05$, and the results of the regression presented as odds ratios (ORs) with a 95\% confidence intervals (CIs).

\section{Results}

\section{Characteristics of the study population}

A description of the study population by background characteristics and empowerment indices is presented in Table 1. Slightly over half of the respondents were from Esan South East LGA. The mean age of the respondents was 30.3 with a standard deviation of $6.8 ; 3 \%$ were less than 20 years old, while $12.5 \%$ were $40-45$ years old. Most of the women were educated, with only about $15 \%$ having no education. Most were working (82.7\%). The majority (72.1\%) owned no land or house, while for $83.2 \%$ their partners or other persons paid for their health care.

Participation in household decisions varied. The decision on how to spend income earned was taken by the respondent and her partner together in $49 \%$ of cases, while $24 \%$ of respondents reported taking the decision alone. As for respondent's health, her partner alone or other persons decided in $50.7 \%$ of cases. About half of the respondents reported that decisions on major purchases in the household were taken by her partner alone or other persons, but daily purchases were a joint decision between the respondent and her partner in $44 \%$ of cases. The decision by the respondent alone was reported by $24.3 \%$ for respondent's income, $11.5 \%$ for her health care, $11.8 \%$ for major purchases, $24.3 \%$ for daily purchases, $8.9 \%$ for visits to family or relatives and $36.6 \%$ for food to be cooked daily.

The majority (63.2\%) of the respondents were affiliated to the various other Christian denominations, married in a monogamous union (68.2\%) and entered into their marital union at age 18 or above $(82.7 \%)$. Many (44\%) were in a union where the partner was 10 or more years older than her. Most $(87 \%)$ were in a union where her partner was more educated or had attained the same level of education as her.

Distribution of the respondents by maternal health service utilization showed that many (72.6\%) reported using a health facility for antenatal, intrapartum and postnatal care, while $27 \%$ did not access all the three levels of care. Close to $60 \%$ of the respondents in Esan South East accessed antenatal, intrapartum and postnatal care in a health facility, compared with about $41 \%$ in Etsako East. A large proportion of women in all age groups obtained all three levels of maternal health care. The distribution within those who attained all three levels of care showed that the lowest number was among women aged 16-19 years old. The association between LGA and maternal health seeking behaviour was statistically significant but insignificant for age. Close to half of the respondents who received all the three levels of maternal care attained secondary or higher education. Ownership of land or house alone, or with a partner, was reported by $17 \%$ of the 
Table 1. Distribution of respondents by background characteristics, women's empowerment indices and utilization of three levels of skilled maternal health care service for their most recent birth in the 5 years before the survey

\begin{tabular}{|c|c|c|c|c|}
\hline \multirow[b]{2}{*}{ Variable } & \multicolumn{2}{|c|}{$\begin{array}{c}\text { Maternal health service } \\
\text { utilization }\end{array}$} & \multirow[b]{2}{*}{ Total } & \multirow[b]{2}{*}{$p$-value } \\
\hline & $\begin{array}{c}\text { Received }<3 \\
n(\%)\end{array}$ & $\begin{array}{c}\text { Received all } 3 \\
n(\%)\end{array}$ & & \\
\hline All respondents & $341(27.4)$ & $904(72.6)$ & $1245(100.0)$ & \\
\hline LGA & & & & $<0.001$ \\
\hline Esan South East & $106(31.1)$ & $537(59.4)$ & $643(51.6)$ & \\
\hline Etsako East & $235(68.9$ & $367(40.6)$ & $602(48.4)$ & \\
\hline Mean (SD) & $29.6(6.6)$ & $30.5(6.9)$ & $30.3(6.8)$ & \\
\hline Age (years) & & & & ns \\
\hline $16-19$ & $9(2.6)$ & $28(3.1)$ & $37(3.0)$ & \\
\hline $20-24$ & $71(20.8)$ & $151(16.7)$ & $222(17.8)$ & \\
\hline $25-29$ & $94(27.6)$ & $234(25.9)$ & $328(26.4)$ & \\
\hline $30-34$ & $73(21.4)$ & $202(22.4)$ & $275(22.1)$ & \\
\hline $25-39$ & $56(16.42)$ & $171(18.9)$ & $227(18.2)$ & \\
\hline $40-45$ & $38(11.14$ & $118(13.1)$ & $156(12.5)$ & \\
\hline \multicolumn{5}{|l|}{ Resource variables } \\
\hline Education & & & & $<0.001$ \\
\hline No education & $171(50.2)$ & $356(39.4)$ & $527(42.33)$ & \\
\hline Primary & $88(25.8)$ & $448(49.6)$ & $536(43.1)$ & \\
\hline Secondary/higher & $82(24.1)$ & $100(11.1)$ & $182(14.6)$ & \\
\hline Employment status & & & & 0.041 \\
\hline Not working & $47(13.8)$ & $169(18.7)$ & $216(17.4)$ & \\
\hline Working & $294(86.2)$ & $735(81.3)$ & $1029(82.7)$ & \\
\hline Ownership of land or house & & & & ns \\
\hline None & $238(69.8)$ & $660(73.0)$ & $898(72.1)$ & \\
\hline Partner alone or other person & $28(8.2)$ & $90(10.0)$ & $118(9.5)$ & \\
\hline Respondent alone & $36(10.6)$ & $59(6.5)$ & $95(7.6)$ & \\
\hline Respondent \& partner & $39(11.4)$ & $95(10.5)$ & $134(10.8)$ & \\
\hline Payment for respondent's health care & & & & 0.024 \\
\hline Partner alone or other person & $296(86.8)$ & $740(81.9)$ & $1036(83.2)$ & \\
\hline Respondent alone & $23(6.7)$ & $58(6.4)$ & $81(6.5)$ & \\
\hline Respondent \& partner & $22(6.5)$ & $106(11.7)$ & $128(10.3)$ & \\
\hline \multicolumn{5}{|l|}{ Decision-making variables } \\
\hline Respondent's income & & & & ns \\
\hline Partner alone or other person & $87(25.5)$ & $243(26.9)$ & $330(26.5)$ & \\
\hline Respondent alone & $81(23.8)$ & $221(24.5)$ & $302(24.3)$ & \\
\hline Respondent \& partner & $173(50.8)$ & $440(48.7)$ & $613(49.2)$ & \\
\hline
\end{tabular}


Table 1. (Continued)

\begin{tabular}{|c|c|c|c|c|}
\hline \multirow[b]{2}{*}{ Variable } & \multicolumn{2}{|c|}{$\begin{array}{c}\text { Maternal health service } \\
\text { utilization }\end{array}$} & \multirow[b]{2}{*}{ Total } & \multirow[b]{2}{*}{$p$-value } \\
\hline & $\begin{array}{c}\text { Received }<3 \\
n(\%)\end{array}$ & $\begin{array}{c}\text { Received all } 3 \\
n(\%)\end{array}$ & & \\
\hline Respondent's health & & & & 0.028 \\
\hline Partner alone or other person & $193(56.6)$ & $438(48.5)$ & $631(50.7)$ & \\
\hline Respondent alone & $38(11.1)$ & $105(11.6)$ & $143(11.5)$ & \\
\hline Respondent \& partner & $110(32.3)$ & 361 (39.9) & 361 (39.9) & \\
\hline Major purchases & & & & 0.009 \\
\hline Partner alone or other person & $194(56.9)$ & $429(47.5)$ & $623(50.0)$ & \\
\hline Respondent alone & $31(9.1)$ & $116(12.8)$ & $147(11.8)$ & \\
\hline Respondent \& partner & $116(34.0)$ & $359(39.7)$ & $475(38.2)$ & \\
\hline Daily purchases & & & & ns \\
\hline Partner alone or other person & $115(33.7)$ & $280(31.0)$ & $395(31.7)$ & \\
\hline Respondent alone & $85(24.9)$ & $217(24.0)$ & $302(24.3)$ & \\
\hline Respondent \& partner & $141(41.4)$ & $407(45.0)$ & $548(44.0)$ & \\
\hline Visits to respondent's family or relatives & & & & ns \\
\hline Partner alone or other person & $134(39.3)$ & $385(42.6)$ & $519(41.7)$ & \\
\hline Respondent alone & $33(9.7)$ & $78(8.6)$ & $111(8.9)$ & \\
\hline Respondent \& partner & $174(51.0)$ & $441(48.8)$ & $615(49.4)$ & \\
\hline Food to be cooked each day & & & & ns \\
\hline Partner alone orother person & $77(22.6)$ & $221(24.5)$ & $298(23.9)$ & \\
\hline Respondent alone & $133(39.0)$ & $323(35.7)$ & $456(36.6)$ & \\
\hline Respondent \& partner & $131(38.4)$ & $360(39.8)$ & 491 (39.4) & \\
\hline \multicolumn{5}{|l|}{ Influencer factor variables } \\
\hline Religion & & & & $<0.001$ \\
\hline Catholic & $118(34.6)$ & $219(24.25)$ & $337(27.1)$ & \\
\hline Other Christian & $185(54.3)$ & $601(66.6)$ & $786(63.2)$ & \\
\hline Islam & $38(11.1)$ & $83(9.2)$ & $121(9.7)$ & \\
\hline Marital status & & & & ns \\
\hline Married & $219(64.2)$ & $630(69.7)$ & $849(68.2)$ & \\
\hline Living together & $122(35.8)$ & $274(30.3)$ & $396(31.8)$ & \\
\hline Age at marriage & & & & 0.027 \\
\hline$<18$ & $72(21.1)$ & $143(15.8)$ & $215(17.3)$ & \\
\hline $18+$ & $269(78.9)$ & $761(84.2)$ & $1030(82.7)$ & \\
\hline Type of marriage & & & & ns \\
\hline Monogamy & $267(78.3)$ & $714(79.0)$ & $981(78.8)$ & \\
\hline Polygyny & $74(21.7)$ & $190(21.0)$ & $264(21.2)$ & \\
\hline Spousal age gap & & & & ns \\
\hline
\end{tabular}


Table 1. (Continued)

\begin{tabular}{|c|c|c|c|c|}
\hline \multirow[b]{2}{*}{ Variable } & \multicolumn{2}{|c|}{$\begin{array}{c}\text { Maternal health service } \\
\text { utilization }\end{array}$} & \multirow[b]{2}{*}{ Total } & \multirow[b]{2}{*}{$p$-value } \\
\hline & $\begin{array}{c}\text { Received }<3 \\
n(\%)\end{array}$ & $\begin{array}{c}\text { Received all } 3 \\
n(\%)\end{array}$ & & \\
\hline Same/wife older/wife $<5$ years younger & $50(14.7)$ & $168(18.6)$ & $218(17.5)$ & \\
\hline Wife $5-9$ years younger & $135(39.6)$ & $344(38.1)$ & $479(38.5)$ & \\
\hline Wife $10+$ years younger & $156(45.8)$ & $392(43.4)$ & $548(44.0)$ & \\
\hline Education difference & & & & $<0.001$ \\
\hline Both no education & $24(7.0)$ & $27(3.0)$ & $51(4.1)$ & \\
\hline Partner $>$ wife & $171(50.2)$ & $364(40.3)$ & $535(43.0)$ & \\
\hline Wife $>$ partner & $24(7.0)$ & $87(9.6)$ & $111(8.9)$ & \\
\hline Same but not none & $122(35.8)$ & $426(47.1)$ & $548(44.0)$ & \\
\hline
\end{tabular}

respondents who obtained all three levels of care, and in about $18 \%$, payment for the respondent's health care services was made by the respondent alone or with their partner. Maternal health service utilization was statistically associated with education, employment status and payment of respondent's health care.

Most respondents who accessed all three levels of maternal care were from households where decisions about respondent's income and daily purchases were made by the respondent and her partner together, and where decisions about respondent's health and major purchases were made by her partner alone or other persons. The majority of the respondents (48.8\%) who received all three levels of care participated jointly with their partners in decisions on visits to the respondent's family or relatives and food to be cooked each day (39.8\%). The relationship between the decisionmaking domain variables and maternal health service utilization was only statistically significant for respondent's health and major purchases.

Receiving all three levels of care was more dominant among respondents who were of 'other Christian' affiliation, legally married, married after age 18 years and in a monogamous union. Reporting the three levels of care was predominant among respondents where the spousal age difference was 5 or more years, and the couple had attained the same level of education. A statistically significant relationship was observed between religion, age at marriage, spousal education difference and utilization of skilled maternal health care.

\section{Multivariable analysis}

The odds of receiving all three levels of maternal health care in a facility for the most recent births in the 5 years before the survey by the different domains of empowerment are presented in Table 2. Adjusting for all resource variables in Model 1, the odds of receiving the three levels of care were $66 \%$ higher for respondents who attained primary education than those who had no education. Similarly, respondents who attained secondary and higher education were 4 times more likely to report having accessed the expected three levels of care relative to their counterparts who were uneducated (OR 4.01, CI: 2.91-8.39). The odds of receiving all three levels of care were higher among respondents who paid for their health care jointly with their partner compared with those who did not participate in paying for their health care (OR 1.80, CI: 1.10-2.96).

In the decision domain (Model 2), compared with no participation, a joint decision by respondent and her partner about the respondent's health predicted higher odds of receiving all three levels of care. Also, relative to no participation, when the respondent alone decided on major 
Table 2. Odds of receiving all three levels of maternal health care by empowerment variables

\begin{tabular}{|c|c|c|c|c|}
\hline Variable & $\begin{array}{c}\text { Model } 1 \\
\text { Resource domain } \\
\text { OR }(95 \% \mathrm{Cl}) \\
\end{array}$ & $\begin{array}{c}\text { Model } 2 \\
\text { Decision domain } \\
\text { OR }(95 \% \mathrm{Cl})\end{array}$ & $\begin{array}{c}\text { Model } 3 \\
\text { Influencer domain } \\
\text { OR }(95 \% \mathrm{Cl}) \\
\end{array}$ & $\begin{array}{l}\text { Full Model } \\
\text { OR }(95 \% \mathrm{Cl})\end{array}$ \\
\hline Education & & - & - & \\
\hline \multicolumn{5}{|l|}{ No education (Ref.) } \\
\hline Primary & $1.66(1.17-2.36)^{\star \star}$ & & & $1.81(1.17-2.79)^{\star \star}$ \\
\hline Secondary/higher & $4.01(2.76-5.84)^{\star \star \star}$ & & & $4.94(2.91-8.39)^{\star \star \star}$ \\
\hline Employment status & & - & - & \\
\hline \multicolumn{5}{|l|}{ Not working (Ref.) } \\
\hline Working & $0.79(0.55-1.14)$ & & & $0.77(0.52-1.13)$ \\
\hline Ownership of land or house & & - & - & \\
\hline \multicolumn{5}{|l|}{ None (Ref.) } \\
\hline Partner alone or other person & $1.20(0.76-1.91)$ & & & $1.13(0.69-1.84)$ \\
\hline Respondent alone & $0.67(0.42-1.05)$ & & & $0.60(0.37-0.97)^{\star}$ \\
\hline Respondent \& partner & $0.77(0.501 .17)$ & & & $0.71(0.45-1.11)$ \\
\hline $\begin{array}{l}\text { Payment for respondent's health } \\
\text { care }\end{array}$ & & - & - & \\
\hline \multicolumn{5}{|l|}{$\begin{array}{l}\text { Partner alone or other person } \\
\text { (Ref.) }\end{array}$} \\
\hline Respondent alone & $1.11(0.66-1.86)$ & & & $1.34(0.72-2.51)$ \\
\hline Respondent \& partner & $1.80(1.10-2.96)^{\star}$ & & & $1.66(0.99-2.80)$ \\
\hline Respondent's income & - & & - & \\
\hline \multicolumn{5}{|l|}{$\begin{array}{l}\text { Partner alone or other person } \\
\quad \text { (Ref.) }\end{array}$} \\
\hline Respondent alone & & $0.93(0.63-1.37)$ & & $0.93(0.62-1.42)$ \\
\hline Respondent \& partner & & $0.76(0.53-1.08)$ & & $0.72(0.49-1.05)$ \\
\hline Respondent's health & - & & - & \\
\hline \multicolumn{5}{|l|}{$\begin{array}{l}\text { Partner alone or other person } \\
\text { (Ref.) }\end{array}$} \\
\hline Respondent alone & & $1.04(0.63-1.72)$ & & $0.84(0.48-1.47)$ \\
\hline Respondent \& partner & & $1.47(1.05-2.05)^{\star}$ & & $1.25(0.88-1.80)$ \\
\hline Major purchases & - & & - & \\
\hline \multicolumn{5}{|l|}{$\begin{array}{l}\text { Partner alone or other person } \\
\text { (Ref.) }\end{array}$} \\
\hline Respondent alone & & $2.20(1.24-3.90)^{\star \star}$ & & $2.31(1.26-4.22)^{\star \star}$ \\
\hline Respondent \& partner & & $1.38(0.98-1.96)$ & & $1.36(0.94-1.96)$ \\
\hline Daily purchases & - & & & \\
\hline \multicolumn{5}{|l|}{$\begin{array}{l}\text { Partner alone or other person } \\
\text { (Ref.) }\end{array}$} \\
\hline Respondent alone & & $0.87(0.58-1.30)$ & & $0.97(0.63-1.48)$ \\
\hline Respondent \& partner & & $1.04(0.72-1.51)$ & & $1.16(0.78-1.72)$ \\
\hline
\end{tabular}


Table 2. (Continued)

\begin{tabular}{|c|c|c|c|c|}
\hline Variable & $\begin{array}{c}\text { Model } 1 \\
\text { Resource domain } \\
\text { OR }(95 \% \mathrm{Cl})\end{array}$ & $\begin{array}{c}\text { Model } 2 \\
\text { Decision domain } \\
\text { OR }(95 \% \mathrm{Cl})\end{array}$ & $\begin{array}{c}\text { Model } 3 \\
\text { Influencer domain } \\
\text { OR }(95 \% \mathrm{Cl})\end{array}$ & $\begin{array}{l}\text { Full Model } \\
\text { OR }(95 \% \mathrm{Cl})\end{array}$ \\
\hline $\begin{array}{l}\text { Visits to respondent's family or } \\
\text { relatives }\end{array}$ & - & & - & \\
\hline \multicolumn{5}{|l|}{$\begin{array}{l}\text { Partner alone or other person } \\
\text { (Ref.) }\end{array}$} \\
\hline Respondent alone & & $0.69(0.41-1.17)$ & & $0.65(0.37-1.16)$ \\
\hline Respondent \& partner & & $0.80(0.59-1.09)$ & & $0.82(0.59-1.14)$ \\
\hline Food to be cooked each day & - & & - & \\
\hline \multicolumn{5}{|l|}{$\begin{array}{l}\text { Partner alone or other person } \\
\quad \text { (Ref.) }\end{array}$} \\
\hline Respondent alone & & $0.76(0.53-1.09)$ & & $0.64(0.44-0.95)^{\star}$ \\
\hline Respondent \& partner & & $0.87(0.61-1.25)$ & & $0.83(0.57-1.22)$ \\
\hline Religion & - & - & & \\
\hline \multicolumn{5}{|l|}{ Catholic (Ref.) } \\
\hline Other Christian & & & $1.77(1.33-2.36)^{\star \star \star}$ & $1.76(1.30-2.38)^{\star \star \star}$ \\
\hline Islam & & & $1.17(0.74-1.85)$ & $1.27(0.77-2.05)$ \\
\hline Marital status & - & - & & \\
\hline \multicolumn{5}{|l|}{ Married (Ref.) } \\
\hline Living together & & & $0.71(0.53-0.94)^{\star}$ & $0.67(0.50-0.90)^{\star \star}$ \\
\hline Age at marriage & - & - & & \\
\hline \multicolumn{5}{|l|}{$<18$ (Ref.) } \\
\hline $18+$ & & & $1.26(0.91-1.74)$ & $0.93(0.69-1.25)$ \\
\hline Type of marriage & - & - & & \\
\hline \multicolumn{5}{|l|}{ Monogamy (Ref.) } \\
\hline Polygyny & & & $1.03(0.75-1.41)$ & $1.20(0.86-1.69)$ \\
\hline Spousal age gap & - & - & & \\
\hline \multicolumn{5}{|l|}{$\begin{array}{l}\text { Same/wife older/wife }<5 \text { years } \\
\text { younger (Ref.) }\end{array}$} \\
\hline Wife $5-9$ years younger & & & $0.78(0.53-1.14)$ & $0.80(0.54-1.19)$ \\
\hline Wife $10+$ years. Younger & & & $0.83(0.56-1.21)$ & $0.90(0.60-1.34)$ \\
\hline Education difference & - & - & & \\
\hline \multicolumn{5}{|l|}{$\begin{array}{l}\text { Both no education Copenhagen } \\
\text { (Ref.) }\end{array}$} \\
\hline Partner $>$ wife & & & $1.76(0.97-3.17)$ & $1.06(0.54-2.10)$ \\
\hline Wife $>$ partner & & & $2.76(1.33-5.69)^{\star \star}$ & $0.77(0.32-1.85)$ \\
\hline Same but not none & & & $2.78(1.53-5.06)^{\star \star}$ & $0.91(0.43-1.96)$ \\
\hline
\end{tabular}


purchases, the odds of receiving all three expected levels of maternal care were 2.20 times higher, and 1.38 times higher when the respondent and partner decided jointly.

In the influencer domain (Model 3), respondents who were of other Christian affiliations were $77 \%$ more likely than Catholics to receive all three levels of care. Compared with respondents who were in a legal marital union, the odds of receiving all three levels of care were lower for those who lived together with a partner in a consensual union (OR 0.71, CI: 0.53-0.94). The likelihood of utilizing all three levels of maternal care were higher when the respondent was more educated than her partner (OR 2.76, CI: 1.33-5.69), and when both had the same level of education (OR 2.78, CI: 1.53-5.06) compared with when both had no education.

When all the domains were adjusted in the full model (Model 4), respondent's level of education remained a significant predictor of utilizing all three levels of maternal care, with respondents who had primary, secondary or higher education being more likely than their illiterate counterparts to receive all three. Ownership of land or house became associated with lower odds of maternal health care utilization compared with those who had none.

In the decision domain, relative to respondents who did not participate in decision-making, the decision on major purchases alone remained a strong predictor of utilization of the three levels of care (OR 2.31, CI: 1.26-4.22). In contrast, when respondents alone decided on food to be cooked each day, the likelihood of using all three levels of maternal health care was less (OR 0.64, CI: 0.44-0.95) relative to where the partner alone or other persons decided.

In the influencer domain, affiliation to other Christian religions remained a significant positive predictor of utilization of all three levels of maternal care relative to Catholics, and respondents in a consensual union remained less likely to use all three maternal health care services compared with those in a legal marital union.

\section{Discussion}

This study examined the influence of women's empowerment indices, measured in the three domains of resource, decision-making and influencer factors, on the odds of using all three levels of maternal health care (antenatal, intrapartum and postnatal) in two rural LGAs in Edo State, Nigeria. Slightly above $72 \%$ of the respondents reported using all three levels of care during the 5 years preceding the survey. This figure seems impressive compared with the current national average of $67 \%$ for antenatal care utilization, $39 \%$ for skilled delivery and $44 \%$ for postnatal care in Nigeria (NPC \& ICF, 2019). However, because most women use primary health care centres (PHCs) located in the study communities, the quality of care they receive is uncertain. Previous studies of PHCs in Nigeria report poor quality service owing to inadequate skilled personnel and lack of adequate medical equipment and infrastructure (Akinyinka et al., 2016; Oyekale, 2017).

Many of the empowerment indicators included in this study were found to be significantly associated with the utilization of all three levels of maternal health care services. When all other factors were held constant, educationally empowered women (attainment of secondary or higher education) were more likely to use all three levels of maternal care compared with their illiterate counterparts. This indicates that female education is a strong predisposing factor for utilization of maternal health services in the study area (Andersen \& Newman, 2005). The finding on education corroborates several past studies in Nigeria and other countries and reinforces the fact that post-primary education for women is key to improving individual-level and population health indicators and achieving development goals (Desai \& Alva, 1998; Ahmed et al., 2010; Smith-Greenaway, 2013; Ononokpono, 2015; UNDP 2018; Ndugga et al., 2020). Indeed, even primary education is far better than none in predicting better child health, and maternal health care utilization, as shown in this study (Smith-Greenaway, 2013; Kifle et al., 2017). Of interest also, is that women in a marital union where the wife was more educated or equally educated than her partner fared better in utilizing the three levels of care than when both spouses had no education. This finding strengthens the 
importance of empowering women with education to achieve health-related outcomes, as shown in past studies that examined the spousal gap in education and health outcomes (Ntoimo \& Mutanda, 2017; Ntoimo \& Chirwa-Banda, 2017). However, when other factors were adjusted, the difference in educational attainment became statistically insignificant, suggesting that when a woman is empowered through education, the spousal difference in education may not be a deterrent to the use of maternal health care services.

Ownership of land or house by the respondent alone predicted lower odds of using the three levels of maternal care. This is not unexpected given that land or a house in a rural area may not provide any source of income for a woman, especially because the quality of such assets may not attract a reasonable monetary value. Also, compared with men, women in many Nigerian communities, as in many African countries, do not own substantial assets that can be translated into strong resource empowerment as many women are still financially dependent on their partners (Yaya et al., 2019). In contrast, joint payment for a woman's health care with a partner contributed positively to the utilization of all three maternal health care services, albeit insignificant in the full model. Existing empirical evidence suggests that dual-income families fare better in health and other welfare outcomes than families with a single source of income (Waite, 1995; Amato, 2000; Allendorf, 2010; Clark \& Hamplová, 2013; Ntoimo, 2015; Banda et al., 2017).

Results in the decision-making domain indicated that joint decision about a woman's health is a significant factor for the use of maternal health services; and participating alone in decisions about major household purchases are predictive of a higher likelihood of using a health facility for all three maternal health care services. On the other hand, participating alone in decisions about food to be cooked each day lowered the odds of using maternal health care services. Increasing participation by women in decision-making within the family is indicative of a decline in patriarchal exploitation occasioned by modernization (Walby, 1989; Giddens, 1992, 2006). However, participation in decisions about food to be cooked each day does not predict a higher likelihood of maternal health service use because domestic chores such as cooking are still considered a woman's sphere in many of Nigeria's patriarchal cultures. Thus, it is a norm that does not ascribe any special empowerment attributes to women.

The influencer factors added to this analysis included religious affiliation, heterosexual familial ideologies and patriarchal norms that still support early marriage and a traditional mate selection pattern where men prefer women who are younger, attractive, less educated and earn less. Among the influencer factors, affiliation to the more liberal Protestant denominations predicted higher odds of utilizing maternal health care services compared with Catholics. Although many studies have observed a higher likelihood of Catholics and other Christians utilizing maternal health care services than Muslims and adherents of traditional religion (Solanke et al., 2015; Somefun \& Ibisomi, 2016; Dansou et al., 2018), comparing Catholics with other Christians is not common except for contraceptive use (Okech et al., 2011; Agadjanian, 2013). A review conducted in the late 1980s showed inconclusive results on the differences in health care utilization between Catholics and other Christians (Schiller \& Levin, 1988). However, the result indicates that religious affiliation is a significant women's empowerment influencer variable (Jejeebhoy \& Sathar, 2001; Seguino, 2011). Women in a consensual union were less likely to use a health facility for all three levels of maternal care compared with legally married respondents. Previous studies have shown that women in consensual union are disadvantaged because their union lacks the commitment that is often associated with a legal marital union, which drives better health outcomes (Waite, 1995; Wu \& Hart, 2002; Holt-Lunstad et al., 2008; Ntoimo et al., 2016).

The study has its limitations. The context of some of the empowerment indices, such as ownership of land or house, was not known because the data were quantitative. Future research on women's empowerment and maternal health should engage multiple methods for an in-depth and contextual explanation of the indices. Also, due to the cross-sectional nature of the data, causality could not be inferred. However, the results provide significant insight into the role of women's empowerment in predicting the pattern of use of maternal health care services in rural areas of Nigeria. 
In conclusion, the findings of this study indicate that, to achieve the SDG-3 in Nigeria, and ensure women's right to maternal health, empowerment indices should be given priority attention in policy and programmes in the country. Health system factors are critical to achieving healthrelated goals, but without interventions geared towards changing gender norms that constrain women's empowerment, access to orthodox maternal care, and maternal health indicators in Nigeria may remain sub-optimal. A composite strategy that targets all women's empowerment indices is recommended, as Nigeria strives towards achieving SDG-3.

Acknowledgements. The contribution of the following persons is acknowledged: Brian Igboin, who supervised, collated and ensured data quality in Etsako East; Francis Igberaese and Joab Oghene, who coordinated data collection in Esan South East and Etsako East, respectively; Michael Ekholuenetale, Michael Alli, Mary-Jane Emiowele, Precious Ntulu, Best Ojemhen, Jessy Ezebuihe, Peace Oppogen, Progress Emoitotoga and Abubakar Zuleya Ogechukwu Onwuma, who were data collectors in the two LGAs; and Evans Ejedenawe, Raphael Okpaire, Cynthia Okojie, Tayo Ozobo, Akingbe Aminat and Ebunu Fatimetu, who served as community focal persons in both LGAs. All these were instrumental in helping the project teams gain access to the project communities.

Funding. This research was supported by the International Development Research Centre (IDRC), Global Affairs Canada (GAC) and Canadian Institute for Health Research (CIHR) under the Innovating for Maternal and Child Health in Africa (IMCHA) (Grant \#108041). The funders played no role in the design of the study, data collection and analysis, interpretation of data or writing of the manuscript.

Conflicts of Interest. The authors have no conflicts of interest to declare.

Ethical Approval. Ethical clearance approval for the project was obtained from the National Health Research Ethics Committee (NHREC) after the submission of the study protocol. The project ethical clearance certificate was approved on 18th April 2017 with NHREC Approval Number: NHREC/01/01/2007-18/04/2017. All the participants received a verbal and written explanation of the research and procedures. When they agreed to participate, a written informed consent was obtained before their participation.

\section{References}

Abada T and Tenkorang EY (2012) Women's autonomy and unintended pregnancies in the Philippines. Journal of Biosocial Science 44(6), 703-718.

Agadjanian V (2013) Religious denomination, religious involvement, and modern contraceptive use in Southern Mozambique. Studies in Family Planning 44(3), 259-274.

Ahmed S, Creanga AA, Gillespie DG and Tsui AO (2010) Economic status, education and empowerment: implications for maternal health service utilization in developing countries. PLoS One 5(6), el1190.

Akinyinka MR, Adebayo B, Wright K and Adeniran A (2016) Client waiting time in an urban primary health care centre in Lagos. Journal of Community Medicine and Primary Health Care 28(1), 17-24.

Akpan EO (2003) Early marriage in eastern Nigeria and the health consequences of vesicovaginal fistulae (VVF) among young mothers. Gender \& Development 11(2), 70-76.

Allendorf K (2010) The quality of family relationships and use of maternal health-care services in India. Studies in Family Planning 41(4), 263-276.

Amato PR (2000) The consequences of divorce for adults and children. Journal of Marriage \& Family 62(4), 1269-1287.

Andersen R and Newman JF (2005) Societal and individual determinants of medical care utilization in the United States. The Milbank Quarterly 83(4), 1-28.

Antai D (2011) Inequalities in under-5 mortality in Nigeria: do ethnicity and socioeconomic position matter? Journal of Epidemiology 21(1), 13-20.

Azuh DE, Azuh AE, Iweala EJ, Adeloye D, Akanbi M and Mordi RC (2017) Factors influencing maternal mortality among rural communities in southwestern Nigeria. International Journal of Women's Health 9, 179-188.

Bamiwuye SO, De Wet N and Adedini SA (2013) Linkages between autonomy, poverty and contraceptive use in two subSaharan African countries. African Population Studies 27(2), 164-173.

Banda PC, Ntoimo LF and Olamijuwon EO (2017) Living arrangements and nutritional status of under-five children in subSaharan Africa. Etude de La Population Africaine 31, 1 S1.

Banda PC, Odimegwu CO, Ntoimo LF and Muchiri E (2016) Women at risk: gender inequality and maternal health. Women \& Health 57(4), 405-429.

Bloom SS, Wypij D and Gupta MD (2001) Dimensions of women's autonomy and the influence on maternal health care utilization in a north Indian city. Demography 38(1), 67-78. 
Boye AK, Hill K, Isaacs S and Gordis D (1991) Marriage law and practice in the Sahel. Studies in Family Planning 22(6), 343-349. Camerini L, Schulz PJ and Nakamoto K (2012) Differential effects of health knowledge and health empowerment over patients' self-management and health outcomes: a cross-sectional evaluation. Patient Education and Counseling 89(2), 337-344.

Chol C, Negin J, Agho KE and Cumming RG (2019) Women's autonomy and utilisation of maternal healthcare services in 31 Sub-Saharan African countries: results from the Demographic and Health Surveys, 2010-2016. BMJ Open 9(3), e023128.

Clark S and Hamplová D (2013) Single motherhood and child mortality in sub-Saharan Africa: a life course perspective. Demography 50(5), 1521-1549.

Dairo M and Owoyokun K (2010) Factors affecting the utilization of antenatal care services in Ibadan, Nigeria. Benin Journal of Postgraduate Medicine 12(1), 3-13.

Dansou J, Adekunle AO and Arowojolu AO (2018) Factors behind institutional delivery preference in the Republic of Benin: an analysis of 2011-2012 Benin Demographic and Health Survey (BDHS) data. Journal of Population and Social Studies 26(2), 128-148.

DeRose LF and Ezeh AC (2005) Men's influence on the onset and progress of fertility decline in Ghana, 1988-98. Population Studies 59(2), 197-210.

Desai S and Alva S (1998) Maternal education and child health: is there a strong causal relationship? Demography 35(1), 71-81.

Dixon-Mueller R (1998) Female Empowerment and Demographic Processes: Moving Beyond Cairo. International Union for the Scientific Study of Population, Paris.

Ebuehi OM and Akintujoye I (2012) Perception and utilization of traditional birth attendants by pregnant women attending primary health care clinics in a rural Local Government Area in Ogun State, Nigeria. International Journal of Women's Health 4, 25.

Edo State Government (2018) Edo State Government Committee Report on Improving Primary Health Care for Maternal and Child Health Care in Edo State. Edo State, Nigeria.

Eshiet UI, Jackson IL and Akwaowoh AE (2016) High patronage of traditional birth homes: a report from Akwa Ibom, Southern Nigeria. American Journal of Health Policy and Management 1(1), 1-6.

Fawole OI and Adeoye IA (2015) Women's status within the household as a determinant of maternal health care use in Nigeria. African Health Sciences 15(1), 217-224.

Federal Government of Nigeria (2013) Integrating Primary Health Care Governance in Nigeria (PHC Under One Roof): Implementation Manual. National Health Care Development Agency.

Galadanci H, Ejembi C, Iliyasu Z, Alagh B and Umar U (2007) Maternal health in Northern Nigeria - a far cry from ideal. BJOG: An International Journal of Obstetrics \& Gynaecology 114(4), 448-452.

Giddens A (1992) The Transformation of Intimacy: Sexuality, Love and Intimacy in Modern Societies. Polity Press, Cambridge.

Giddens A (2006) Sociology, 5th edition. Polity Press, Cambridge, UK.

Gram L, Morrison J and Skordis-Worrall J (2019) Organising concepts of 'women's empowerment' for measurement: a typology. Social Indicators Research 143(3), 1349-1376.

Hakim C (2010) Erotic capital. European Sociological Review 26(5), 499-518.

Holt-Lunstad J, Birmingham W and Jones BQ (2008) Is there something unique about marriage? The relative impact of marital status, relationship quality, and network social support on ambulatory blood pressure and mental health. Annals of Behavioral Medicine 35(2), 239-244.

Izugbara CO (2004) Patriarchal ideology and discourses of sexuality in Nigeria. Understanding Human Sexuality Seminar Series 2, 1-35.

Izugbara CO and Ezeh AC (2010) Women and high fertility in Islamic northern Nigeria. Studies in Family Planning 41(3), 193-204.

Jejeebhoy SJ and Sathar ZA (2001) Women's autonomy in India and Pakistan: the influence of religion and region. Population and Development Review 27(4), 687-712.

Kifle D, Azale T, Gelaw YA and Melsew YA (2017) Maternal health care service seeking behaviors and associated factors among women in rural Haramaya District, Eastern Ethiopia: a triangulated community-based cross-sectional study. Reproductive Health 14(1), 6.

March C, Smyth IA and Mukhopadhyay M (1999) A Guide to Gender-Analysis Frameworks. Oxfam.

Mosedale S (2005) Assessing women's empowerment: towards a conceptual framework. Journal of International Development 17(2), 243-257.

NPC and ICF (2019) Nigeria Demographic and Health Survey 2018. National Population Commission (Nigeria), Abuja, Nigeria, and ICF, Rockville, MD, USA.

Ndugga P, Namiyonga NK and Sebuwufu D (2020) Determinants of early postnatal care attendance: analysis of the 2016 Uganda Demographic and Health Survey. BMC Pregnancy and Childbirth 20(1), 163.

Ntoimo LFC (2015) Does singleness undermine women's health? Evidence from two sub-Saharan African countries. In Wusu O, Nwokocha E and Ntoimo L (eds) Demographic Issues in Nigeria: Insights and Implications. AuthorHouse, Bloomington, IN, pp. 172-200. 
Ntoimo LFC and Chirwa-Banda P (2017) Examining the role of couples' characteristics in contraceptive use in Nigeria and Zambia. African Journal of Reproductive Health 21(4), 93-101.

Ntoimo LFC and Mutanda N (2017) Homogamy and heterogamy in sub-Saharan Africa: implications for couples' fertility behaviour. Development Southern Africa 34(6), 670-681.

Ntoimo LFC, Odimegwu CO, Dansou J and Ola TM (2016) Consensual union in West Africa. African Population Studies 30(2), 2416-2430.

Ntoimo LFC and Odusina EK (2019) Family structure, women autonomy and utilization of maternal healthcare services in Nigeria. In Nwokocha E \& Fayehun O (eds) Concise Demography of Nigeria. BumbleBee Publishing, Ibadan, Nigeria, pp. 124-143.

Ntoimo LFC, Okonofua FE, Igboin B, Ekwo C, Imongan W and Yaya S (2019) Why rural women do not use primary health centres for pregnancy care: evidence from a qualitative study in Nigeria. BMC Pregnancy and Childbirth 19(1), 1-13.

Okech TC, Wawire NW and Mburu TK (2011) Contraceptive use among women of reproductive age in Kenya's city slums. International Journal of Business and Social Science 2(1), 22-43.

Okonofua FE, Ntoimo LFC, Ogungbangbe J, Anjorin S, Imongan W and Yaya S (2018) Predictors of women's utilization of primary health care for skilled pregnancy care in rural Nigeria. BMC Pregnancy and Childbirth 18, 106.

Oladeji D (2008) Communication and decision-making factors influencing couples interest in family planning and reproductive health behaviours in Nigeria. Studies of Tribes and Tribals 6(2), 99-103.

Ononokpono DN (2015) Maternal health care in Nigeria: do community factors moderate the effects of individual-level education and ethnic origin? African Population Studies 29(1), 1554-1569.

Oyekale AS (2017) Assessment of primary health care facilities service readiness in Nigeria. BMC Health Services Research 17, 172.

Sano Y, Sedziafa AP, Vercillo S, Antabe R and Luginaah I (2018) Women's household decision-making autonomy and safer sex negotiation in Nigeria: an analysis of the Nigeria Demographic and Health Survey. AIDS Care 30(2), $240-245$.

Schiller PL and Levin JS (1988) Is there a religious factor in health care utilization? A review. Social Science \& Medicine 27(12), 1369-1379.

Seguino S (2011) Help or hindrance? Religion's impact on gender inequality in attitudes and outcomes. World Development 39(8), 1308-1321.

Sialubanje C, Massar K, Hamer DH and Ruiter RA (2015) Reasons for home delivery and use of traditional birth attendants in rural Zambia: a qualitative study. BMC Pregnancy and Childbirth 15(1), 216.

Smith-Greenaway E (2013) Maternal reading skills and child mortality in Nigeria: a reassessment of why education matters. Demography 50(5), 1551-1561.

Solanke BL, Oladosu OA, Akinlo A and Olanisebe SO (2015) Religion as a social determinant of maternal health care service utilisation in Nigeria. African Population Studies 29(2), 1868-1881.

Somefun OD and Ibisomi L (2016) Determinants of postnatal care non-utilization among women in Nigeria. BMC Research Notes 9(1), 21.

Sripad P, Warren CE, Hindin MJ and Karra M (2019) Assessing the role of women's autonomy and acceptability of intimate-partner violence in maternal health-care utilization in 63 low-and middle-income countries. International Journal of Epidemiology 48(5), 1580-1592.

Titus R, Sengupta D and Madan S (2017) A woman as a decision-maker: exploring the "lived experience" at home and outside. The Qualitative Report 22(5), 1379.

UN Women (2014) Beijing Declaration and Platform for Action. UN Women, New York.

UNDP (2018) Human Development Indices and Indicators 2018 Statistical Update. United Nations Development Programme, New York.

United Nations (1995) World Summit for Social Development 1995, Copenhagen. United Nations. URL: https://digitallibrary. un.org/record/198966 (accessed 4th May 2020).

Upadhyay UD, Gipson JD, Withers M et al. (2014) Women's empowerment and fertility: a review of the literature. Social Science \& Medicine 115, 111-120.

Upadhyay UD and Hindin MJ (2005) Do higher status and more autonomous women have longer birth intervals? Results from Cebu, Philippines. Social Science \& Medicine 60(11), 2641-2655.

Waite LJ (1995) Does marriage matter? Demography 32(4), 483-507.

Walby S (1989) Theorising patriarchy. Sociology 23(2), 213-234.

WHO (1978) Declaration of Alma-Ata: International Conference on Primary Health Care, Alma-Ata, USSR, 6-12th September 1978. URL: http://www.who.int/hpr/NPH/docs/declaration_almaata.pdf (accessed 14 ${ }^{\text {th }}$ February 2006).

WHO (2014) Consultation on Improving Measurement of the Quality of Maternal, Newborn and Child Care in Health Facilities. World Health Organization, Geneva.

WHO (2015a) Trends in Maternal Mortality: 1990 to 2015. Estimates by WHO, UNICEF, UNFPA, The World Bank and the United Nations Population Division. World Health Organization, Geneva.

WHO (2015b) Every Woman, Every Child, Every Adolescent: Achievements And Prospects: The Final Report of the Independent Expert Review Group on Information and Accountability for Women's and Children's Health. World Health Organization, Geneva. 
WHO (2015c) WHO Recommendations on Health Promotion Interventions for Maternal and Newborn Health 2015. World Health Organization, Geneva.

WHO (2016) World Health Statistics 2016: Monitoring Health for the SDGs. World Health Organization, Geneva.

Woldemicael G (2007) Do Women with Higher Autonomy Seek More Maternal and Child Health-Care? Evidence from Ethiopia and Eritrea. Max Planck Institute for Demographic Research, Rostock, Germany.

Woldemicael G (2009) Women's autonomy and reproductive preferences in Eritrea. Journal of Biosocial Science 41(2), 161-181.

Wu Z and Hart R (2002) The effects of marital and nonmarital union transition on health. Journal of Marriage and Family 64(2), 420-432.

Yaya S, Okonofua F, Ntoimo L, Udenige O and Bishwajit G (2019) Gender inequity as a barrier to women's access to skilled pregnancy care in rural Nigeria: a qualitative study. International Health 11(6), 551-560.

Cite this article: Ntoimo LFC, Okonofua FE, Aikpitanyi J, Yaya S, Johnson E, Sombie I, Aina O, and Imongan W (2022). Influence of women's empowerment indices on the utilization of skilled maternity care: evidence from rural Nigeria. Journal of Biosocial Science 54, 77-93. https://doi.org/10.1017/S0021932020000681 